Vol. 4, Issue 2, July 2021

\title{
Developing Pandemic Comics for Youth Audiences
}

\author{
Judy Diamond ${ }^{1}$, Amy Spiegel ${ }^{2}$, Trish Wonch Hill'2, Elizabeth VanWormer ${ }^{3}$, Judi gaiashkibos ${ }^{4}$, Bob Hall ${ }^{5}$, Aaron \\ Sutherlen $^{6}$, and Julia McQuillan \\ ${ }^{1}$ Museum and Libraries, ${ }^{2}$ Methodology \& Evaluation Research Core Facility, and Departments of ${ }^{3}$ Veterinary Medicine, ${ }^{6}$ Art and Art History, and ${ }^{7}$ Sociology, University \\ of Nebraska - Lincoln and ${ }^{4}$ Nebraska Commission on Indian Affairs, ${ }^{5}$ Lincoln, Nebraska
}

Keywords: Comics, graphics, COVID-19, pandemic, STEM, youth, Tribal, Native American, virology, epidemiology

Publication Date: July 19, 2021

DOI: https://doi.org/10.15695/stem/v4i2.03

\begin{abstract}
In spring 2020 our team received funding from the Rapid Response Research program of the National Science Foundation to develop comics that would help youth understand the COVID-19 pandemic. Our project built on a decade of expertise creating comics about the biology of viruses. In collaboration with virologists and artists, we developed three comic stories about COVID-19 during the pandemic and posted them on-line during the last half of 2020. The fictional narratives address fundamental issues in biology, virology, and network science, in order to help readers understand the complexities of living through a viral pandemic. The stories focus on three themes: the biology and social context of the COVID-19 virus; the relationship of wild animals, particularly bats, to the pandemic; and the impact of the pandemic on Tribal communities. We describe the challenges of comic development during the pandemic and the feedback from youth on whether the comics were appealing, interesting, and understandable. The stories were posted on worldofviruses.unl.edu and are published by the University of Nebraska Press as the book, C'RONA Pandemic Comics, with essays for youth about the virus and the pandemic.
\end{abstract}

\section{INTRODUCTION}

In 2020 people around the globe were shaken by the emergence of a new viral pandemic. Schools, businesses, and houses of worship around the world shut their doors to protect people from the new coronavirus, SARS-CoV-2, instantly changing the norms of daily life. Young people tried to make sense of the COVID-19 pandemic as they sought sources of information to help them answer how the virus works. Why is it more dangerous for some people than others? What can be done to protect people from its impacts? How do we make sense of a threat we cannot see? In our massively connected world, information is readily available, but it comes with innuendo, hearsay, and gossip. There is an urgent need for channels of communication that engage youth in ways that will lead them to discern high quality scientific information.

The SARS-CoV-2 virus continues to challenge public health readiness throughout the world. In the United States, Black and Hispanic communities have experienced disproportionate losses, and many Native American communities have been devastated (Tai et al. 2021). There continues to be a great need for educational materials that can help young people understand the pandemic. It may not be enough just to command children to follow guidelines to stay safe. The rules of wearing masks and distancing can only be fully embraced when young people begin to understand the reasons for the protective measures. This requires educators to make the effort to create materials that will engage youth with the underlying knowledge that drives the rules of preventative behavior.

The science of viruses was not specifically included in curricula or in the Next Generation Science Standards until high school (National Research Council 2012, NGSS Lead States 2013). Before high school, students are introduced to viruses in health classes where the focus is on safe behavior, particularly with regard to sexually transmitted diseases. This means that students have relatively few opportunities in school to learn how viruses reproduce, how they cause disease, what makes them difficult to control, and how they in- 
teract with the body's immune system (Diamond et al. 2015; Diamond et al. 2016).

Since 2007, with grants funded by the Science Education Partnership (SEPA) program of the National Institutes of Health, our team has developed and distributed educational materials about viruses and infectious disease for adolescents and adults. We produced popular radio programs about viral outbreaks, developed narrative comics and accompanying interactive apps, created illustrations of common viruses that could be incorporated into papers, collected existing educational virus activities aimed at K-12 audiences and had them reviewed by teachers and virologists, ran afterschool and summer programs on viruses, and working with the science journalist, Carl Zimmer, developed the popular book, A Planet of Viruses, now in its third edition and available in over a dozen languages (Zimmer 2021). All of our materials were made available on our website: worldofviruses.unl. edu. As we explored diverse means for engaging youth with the science of viruses, one medium - comics - stood out from the rest.

Youth librarians advised us that one way to interest adolescents in the biology of viruses would be to create comics that wove together scientific content with fictional narratives. At that time, comic books were experiencing a resurgence of popularity among pre-teens and teenagers, and librarians were observing their wide appeal. This resurgence in popularity led us to spend a decade creating comics about viruses and other microbes. World of Viruses (Diamond et al. 2012) was followed by Carnival of Contagion (Hall et al. 2017), Occupied by Microbes (Diamond et al., 2019), and Mosquitos SUCK! (Bruna et al., 2021). These comics have reached over thirty thousand homes, classrooms, and libraries.

Publication of the comics was built on and extended a research program that examined the impacts of comics on youth understanding of viruses. The early studies laid the groundwork by examining the kinds of mental models that youth have about viruses and how those differ from teachers' and virologists' mental models (Jee et al., 2015). We followed this investigation by seeing how the cognitive and affective impacts of comic stories about viruses compared to non-fiction essays that contained the same science content. This study demonstrated the value of comics for engaging youth with scientific information, particularly among youth with lower science identities (Spiegel et al., 2013). As we began to learn how our comics were being used in classrooms, we found that teachers used them not only to interest students in science, but also to promote equity (Matuk et al., 2019).

In the middle of the 2020 pandemic, our group of educators and scientists was funded for one year by the Rapid Response Research program of the National Science Foundation to create a project with the following three objectives: 1) leverage learning research approaches to better un- derstand current youth conceptual understandings during a pandemic and how, during a crisis, science comic narratives impact youth understanding of and curiosity about science; 2) develop comic stories that will interest and engage diverse youth in grades six through eight to learn more about the basic biology of COVID-19; and 3) mobilize our partnerships with a publisher, schools, libraries, and museums to give youth direct access to the comic stories in print and digital forms. Importantly, the team for creating, evaluating, and researching the comics was largely in place in Nebraska, since nearly all of us had worked together on prior NSF- and NIH-funded projects.

\section{METHODS}

Comic Development During a Pandemic. Under the best of circumstances, the creation of science comics is a challenging endeavor. It requires a synergy of scientific, artistic, and entertaining elements to produce stories of educational value. Comics are a sequential, narrative art that engages the reader with stories that have emotional impact. They are a highly visual media form that incorporates social-emotional content in storytelling. Whereas many comics tell entirely fictional stories, science comics attempt to weave dramatic stories around scientific information, images, and role models.

Many researchers emphasize the role that social emotional content plays in STEM learning (e.g. Hoffman, 2009; Jagers et al., 2019; Taylor et al., 2017). The integration of emotional content and scientific information makes comics a valuable tool for sparking interest in youth, particularly those who show little prior interest in STEM (Hosler and Boomer, 2011; Jee and Angorro, 2012; Matuk et al., 2009; Spiegel et al., 2013; Tatalovic, 2009). One benefit of science comics lies in their ability to draw youth into learning about content that might not ordinarily interest them.

Our prior work on the emergence of science identities among middle school youth supports the idea that exposure to images of scientists, including women and Black, Indigenous, and other people of color, is associated with higher science identities (Gauthier et al., 2017; Hill et al., 2017). In addition, youth who find science more relevant and enjoyable have higher science identities (Hill et al., 2018). Developing more culturally relevant and enjoyable narratives that feature characters from underrepresented communities in science therefore has the potential to engage youth who otherwise might self-select out of science based upon their identities (Kim et al., 2018).

Youth of today are familiar with graphics of exceptionally high quality in the course of gaming, and they expect educational materials to have similar standards. This means that science comics have a high bar to reach in order to be taken seriously by youth. To achieve a professional level 


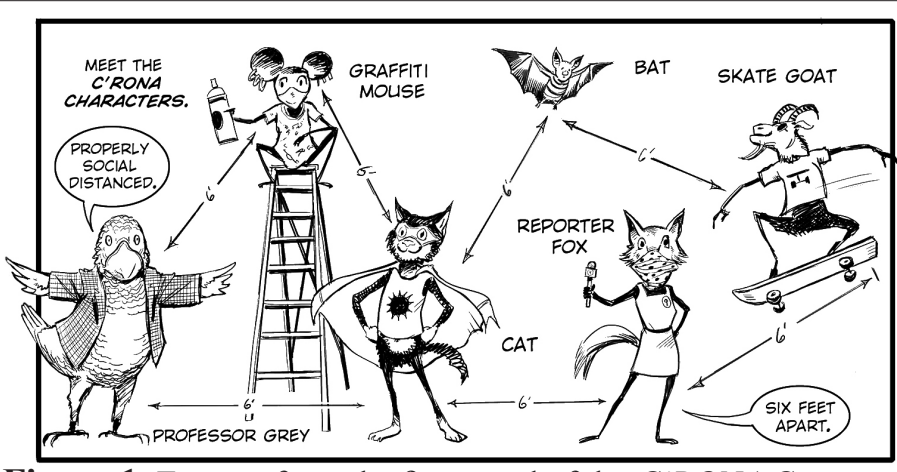

Figure 1. Excerpt from the first panel of the C'RONA Comix.

comic art quality, this project worked with local artist and writer Bob Hall, who worked for Marvel, DC, and Valiant Comics, drawing characters that include The Avengers, Thor, Spider-man, The Fantastic Four, Batman, Shadowman, and Doctor Doom. Hall enlisted the help of cartoonist Bob Camp, best known for his work on Nickelodeon's The Ren and Stimpy Show, and Ho-Chunk artist and member of the Nebraska Winnebago Tribe, Henry Payer.

Comic development requires a sequence of steps: character development, narrative outline and script writing, rough story layout, readjustment and alignment of sequential graphics and script, inking, insertion of text balloons, proofing, and where needed, coloring. At nearly every stage of the process, the ongoing COVID-19 pandemic posed unique challenges to creating entertaining and accurate comics that could be released to the public on a weekly basis.

Character development and script writing was a highly collaborative process that involved the project team, graduate students, virologists, and representatives of Tribal communities. We first struggled with how to create a series of original characters who would be entertaining but who could also communicate information about the virus and the pandemic. We searched for characters with whom youth could broadly identify (see figure 1). Our feedback from teenagers suggested it was more important that the characters had abilities that youth could admire (graffiti artist, skate boarder) or were conceptually familiar (reporter, assassin) than that they were human. We created one character, a parrot professor, who would explain the science to the others, and another, a sensible bat, who would communicate with other wildlife. We gave emotional states to every character, including the viruses, the immune cells, and all the animals. These characters were boastful, sad, fearful, risk taking, kind, and goofy. Most of all, the central characters were bound together by mutual respect and friendship.

The role of fantasy in educational comics may be one of their most controversial aspects (Locke, 2005). Little is known about the ability of youth to separate fantastic from the scientific elements of comics. Our previous studies found that most youth have the ability to differentiate between fantasy and science, even in the same story. In one randomized study, tenth graders given the World of Viruses comics displayed as much scientific content knowledge about viruses as those given non-fiction essays with the same information (Spiegel et al., 2013). Jee and Angorro (2012) argue that comics make scientific concepts and principles more concrete especially with regard to phenomena, such as microscale chemical and biological processes, and this includes fantastic abilities, like the ability to zoom in and out of the frame.

In our COVID-19 stories, the characters ride in a fictional transporter pod to observe how the SARS-CoV-2 viruses infect cells and how they are demolished by immune cells. All of the characters talk, even though they are not human. Early in the pandemic it was not clear which animals other than humans could get sick from the COVID-19 virus, and we were concerned that there might be confusion about whether the non-human characters would legitimately need to worry about getting sick. One attempt to resolve these concerns was to make explicit that the comic allowed certain license; characters could be animals, but they could also represent some human qualities. And we purposely allowed the characters to sometimes break the fourth wall to step out of the comic's reality into the reader's world. For example, as shown in figure 2, the cat asks, "As a cartoon character, am I a cat or a person?" The parrot replies, "Actually as drawn, you are both. And so are the rest of us." A few panels later, the bat says, "I don't have a mask... But I believe in masks. Masks protect my friends... my family... everyone around me. Why don't I have one?" Then he says, "It's because the cartoonist drawing this strip didn't give me one." In the next panel he is wearing a mask and says, "Thanks."

In June 2020, much was not yet known about SARSCoV-2 and scientific information was unsettled. We were concerned about how to get the science right when fundamental information was still just emerging. We tried to focus on reliable information we had at the time and not to speculate on things that were not yet fully agreed upon by the scientific community. We met regularly over Zoom with
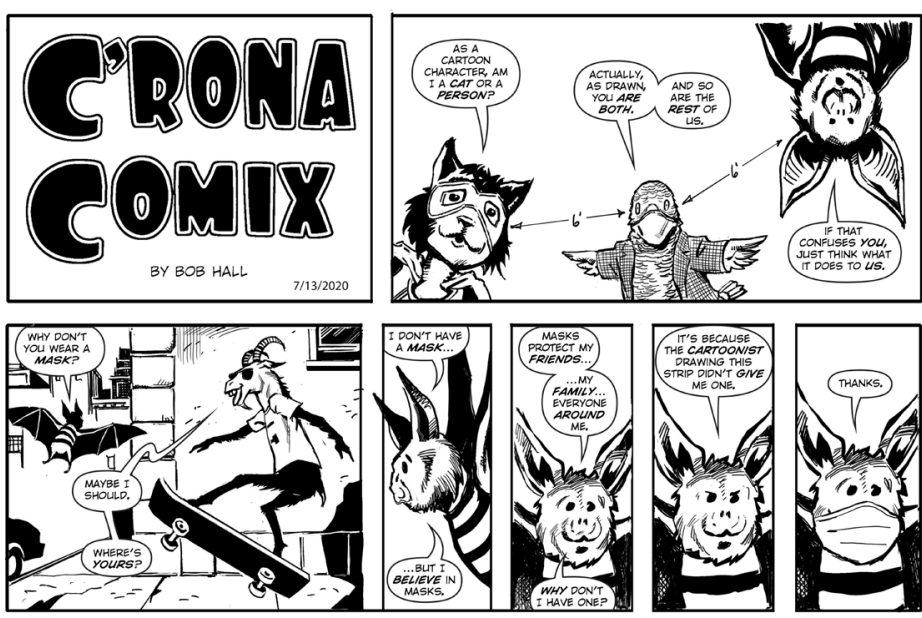

Figure 2. Excerpt from $C^{\prime} R O N A$ Comix, p. 3. 


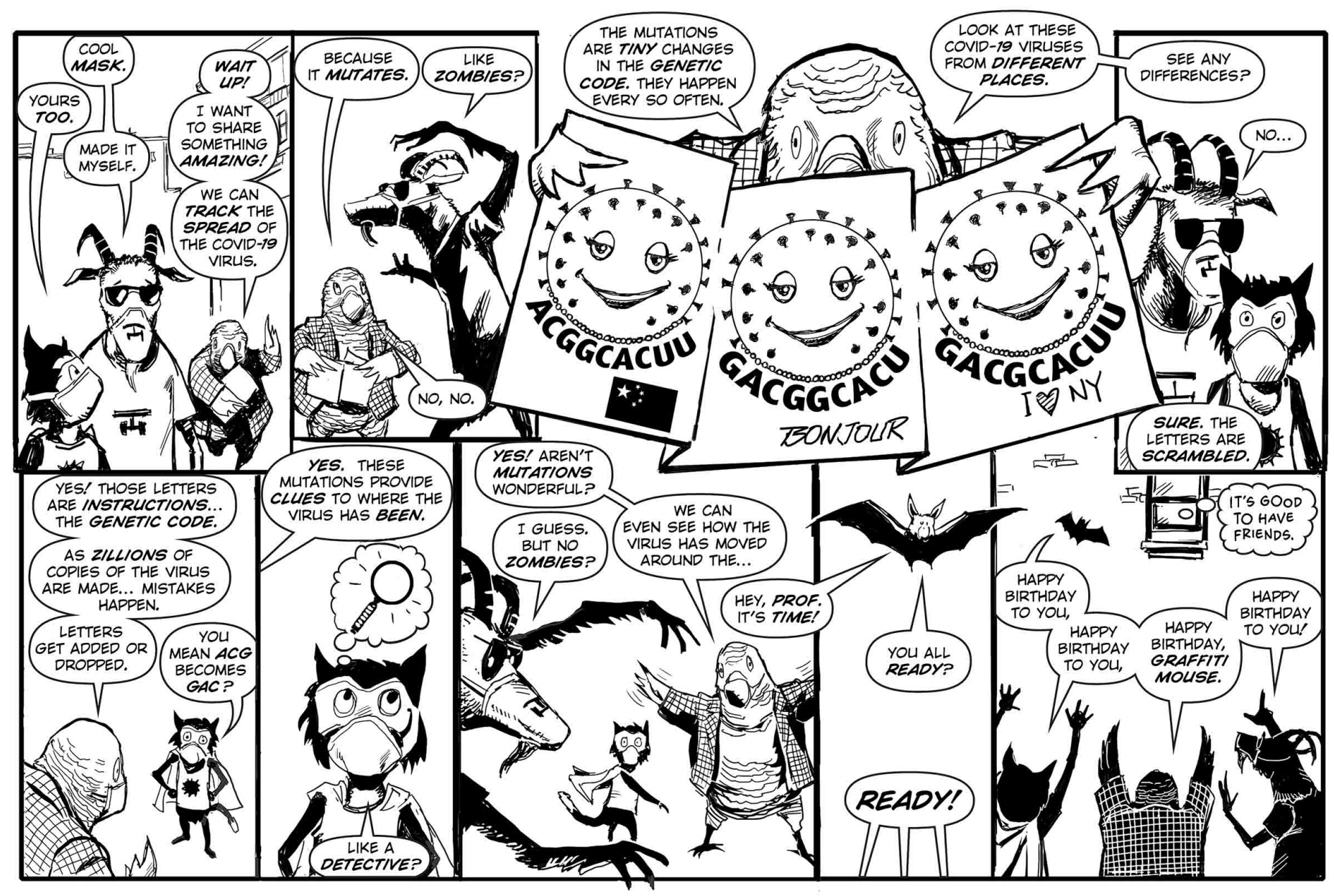

Figure 3. Excerpt from C'RONA Comix, p. 4.

virologists who assisted us and verified our content. The characters wore masks and kept distanced, and early on they met the COVID-19 virus and learned it was not like the flu. The group discovered how changes in the genetic code create variations that are used to trace how the virus spreads (figure 3), and they attempted to create a network map of its transmission (figure 4).

Over the course of the comics one character became sick with COVID-19 and was quarantined at home, and a human
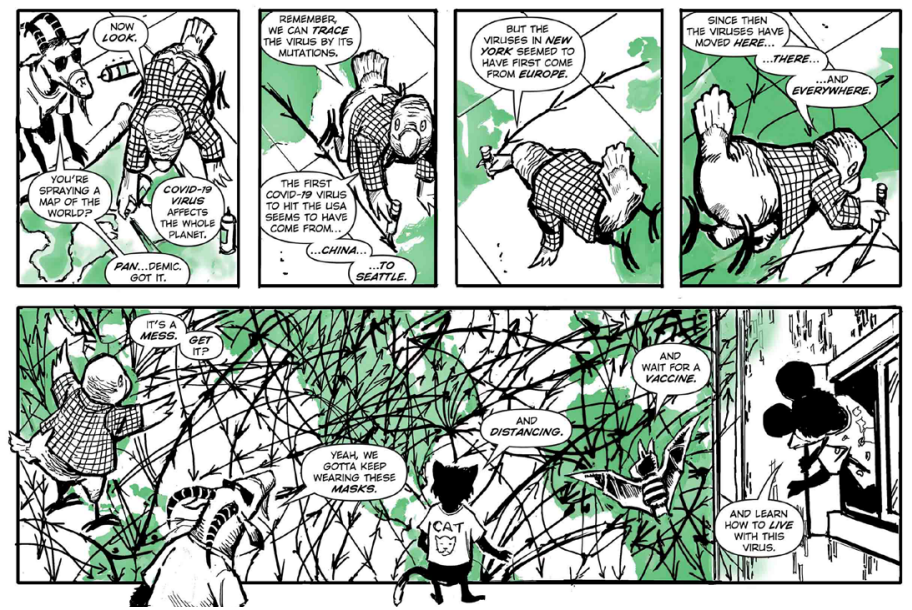

Figure 4. Excerpt from C'RONA Comix, p. 5. grandmother had to be hospitalized. In a special transporter, the animals shrank to a microscopic level and met an army of COVID-19 viruses inside the grandmother, who ultimately recovered (figure 5). Eventually, the immune system's blob-like macrophages, rock climber B-cells, and assassin T-cells defeated the viruses.

Our story about bats introduces the characters to the relationship between wildlife and the spread of viral disease as well as the positive roles that bats play in ecosystems. Al-
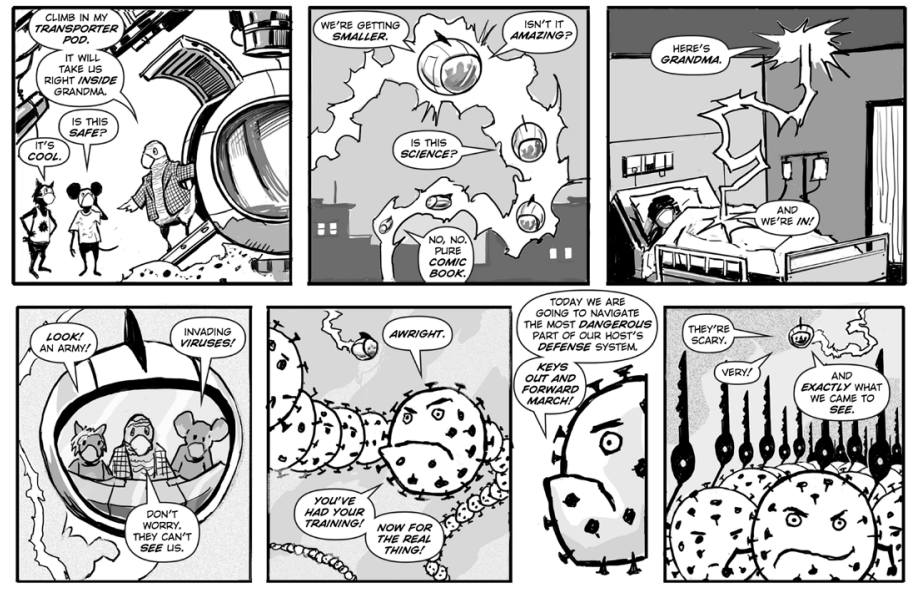

Figure 5. Excerpt from $C^{\prime} R O N A$ Comix, p. 6. 
though bats have a closely related virus to SARS-CoV-2, we were careful not to assume that the COVID-19 disease in humans was directly transmitted from bats. We did, however, introduce the characters to other viral diseases where a clear transmission from bats is known. The professor demonstrated how SARS resulted from viral transmission from bats to civets to people, and how MERS involved a route from bats to camels to humans (figure 6). The group visits a farm near a deforested tropical site where pigs contacted bat saliva infected with the Nipah virus. Civets and pangolins complain that they get blamed for causing the COVID-19 pandemic, but the professor says, "That's a mystery... Scientists are looking for answers right now."

Through the efforts of a local high school science teacher, we were able to receive feedback from 91 high school students (56\% male, $38 \%$ female, $5 \%$ other) enrolled in introductory biology classes (Spiegel, 2021). After reading the comics on the World of Viruses website, students completed a survey on the Qualtrics website. These students ranged in age from 14 to 17, with the large majority 15 years old. Our target age group was middle school, but we nonetheless felt feedback from these slightly older youth would be articulate, and they would be knowledgeable about what would appeal to the younger age group.

Overall, the majority of students agreed that the comics were interesting $(72 \%)$, fun $(60 \%)$, important $(83 \%)$, and amusing (52\%). Nearly $90 \%$ said the comics were somewhat or very easy to understand. About $20 \%$ thought they were boring, and about $10 \%$ found them confusing. The majority of students thought that the health information in the comics was mostly accurate (57-79\%) and a smaller proportion thought the science information was accurate (44-65\%). A minority of students (7-16\%) questioned the accuracy of the comics' health and science information. A large majority indicated that they might or would recommend them to a friend $(89 \%)$ and were even more likely to recommend them to someone younger $(92 \%)$. Between 75 and $80 \%$ of students indicated that they might or would want to read more
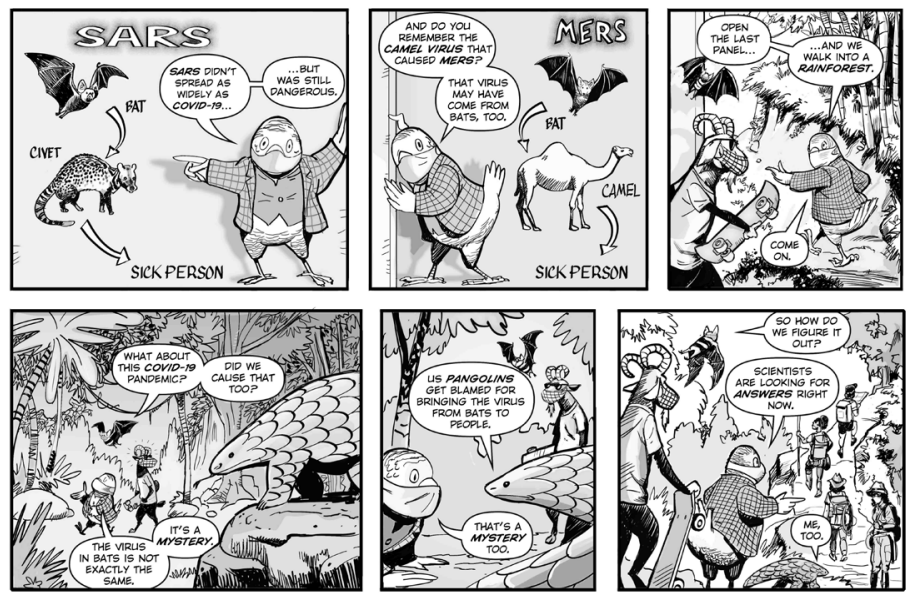

Figure 6. Excerpt from C'RONA Comix II, p. 2. comics like these.

The high school students were articulate in both their positive and negative comments. Several acknowledged that the comics would appeal to younger students:

"Sometimes it's like is more so directed to younger kids, and i get it its good to teach the younger kids but i feel like older kids would like some deep parts. Like there was a part where the mouse was sick and she was alone and she said she was scared and the page was dark. That hit really hard because I've been scared too and it helps the comic look a little more real feeling."

"its about animal characters talking about "c rona" and actually dealing with the physical corona virus. has alot of broken fourth wall jokes that connect the comic with the readers. its funny for younger children who would be learning about the pandemic and older people who would get the jokes inside the comic."

"C'RONA comix are meant to teach younger kids about COVID-19, but it is a really fun way to learn about this virus and how easy it can be to catch it. I would definitely recommend it, and you should read it to know a little more about the pandemic. It might be a little all over the place and confusing but at the end you'll understand the meaning and message behind the comic."

Other high school students responded positively to the comics and repeated content they had learned:

"I would say that the comic was funny in some parts and that it's very important to read because it's what we're going through too, and that we need to keep our distance and we need to have on our masks even though we don't want to."

"I would tell them this is a cool comic with somewhat accurate information on Covid-19 and what it does inside your body and what your body does to counter it and kill off the virus."

"I like the viruses' determination and charisma. They were purposely trying to invade the immune system of a grandmother and fought against the T-cells and the B-cells. I also like the transporter pod that shrinks to get into grandmother to experience and maybe prevent the viruses, which is really cool."

"I would describe it as interesting and it got me hooked on it and it showed a really good way on 
how the virus would spread and be exterminated."

"I don't know a lot about what scientist think started the virus I think the most common theory is bats but I think they should be protected because it isn't their fault it's not like they knew this would happen and they still do a lot for our planet."

Supporting our prior work that comics don't appeal to everyone, some high school students showed no interest in the comics or felt they were confusing or untrustworthy:

"Hey if u like comics $u$ can check this out i personally don't like comics but if u do check this out."

"The word and facts were everywhere and not placed very well."

"I don't have a lot of knowledge about the subjects and $i$ don't always trust everything $i$ read on the internet."

"I honestly don't like how it ends. I also don't like how Professor Grey tracing on the floor, because these lines are literally all over the place, and I wouldn't even remember a single thing for that line. I don't have the intelligence like Professor Grey."

Still others responded positively to the humor:

"That they had facts that help stop the spread of covid while being funny at the same time."

"I like that it isn't exactly all serious but puts a fun twist while still teaching you about not only COVID-19 but other viruses and how your body fights them off."

"I like them because they are easy to read and it has pictures so then you don't have to imagine what's going on because it already shows you."

"one thing that I like about the comics is that it tells true things and also its a comic."

The results of the surveys provide evidence that comics can be an effective medium for helping youth understand the biology of a pandemic while it is occurring. But the preliminary evaluation findings also provide a reminder that a one-size-fits all approach to pandemic education is not likely to be the most successful strategy. Many students liked comics, understood them implicitly, and showed preferences for learning from this medium. Our previous research (Spiegel et al., 2013) suggests that comics are an effective medium for encouraging interest in viruses for students who are initially less interested in science. This, however, is likely only part of the story. There were other students for whom this was not the preferred medium for learning new information and they found the comics confusing.

\section{Development of a Pandemic Comic for Tribal Audiences.}

From the onset, we planned to create a comic story that would be meaningful for Tribal audiences. As terrifying as the pandemic has been for all people, it has proven especially destructive to Native Americans, Black Americans, and Hispanic Americans who are more likely than others to die from COVID-19 (Chu et al., 2021). Many Native communities lack adequate resources to fight the pandemic since they live in remote areas where water is scarce, without the opportunity to wash hands many times each day (Yellow Horse et al., 2021). Despite the extreme hardships, Native communities have joined forces to protect their wellbeing by restricting travel from outsiders onto their lands and setting up testing stations to screen people for the virus. Tribal medical professionals visit families living in remote areas to test who might have the virus, and they get medical treatment to those who need it.

Judi gaiashkibos, director of the Nebraska Indian Commission, led the writing team for the creation of the Tribal C'RONA Comix (Figure 7). For the sequential art, she enlisted Ho-Chunk artist Henry Payer to work with the artist Bob Hall. Our goal was to tell a story about the pandemic from a Tribal perspective. Our challenge was to acknowledge the

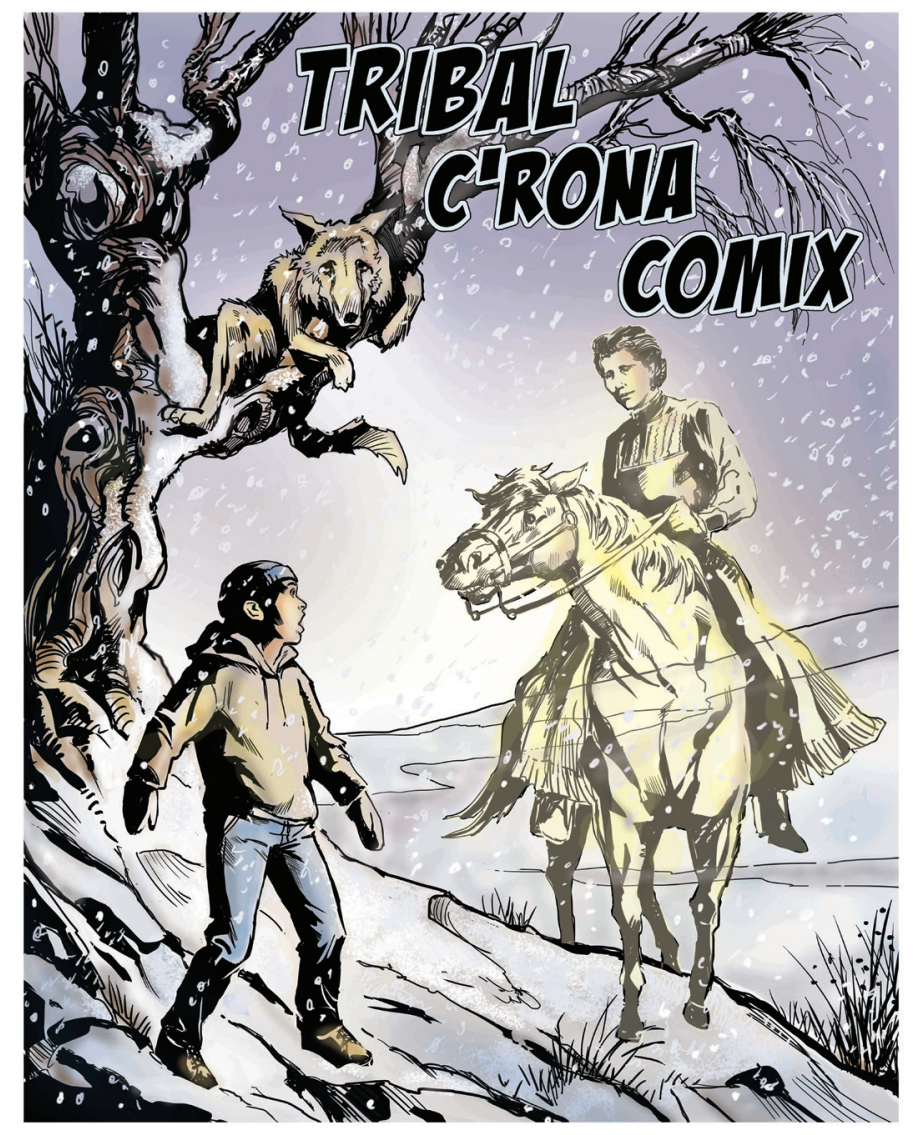

Figure 7. Cover of the Tribal C'RONA Comix. 
devastating impacts of the pandemic on Tribal communities, and at the same time provide positive role models, a sense of hope, and even a sense of playfulness in the midst of resilience. Tribes have survived and sometimes even flourished in the face of discrimination, oppression, a history of forced removal from their homelands, and prior attempts to extinguish entire communities through exposure to viruses, such as smallpox.

As we attempted to convey the difficulties faced by Tribal communities, Judi gaiashkibos emphasized the importance of including traditional positive elements of humor, hope, and the close ties that bind Tribe members together. These were recurrent themes that were reinforced as we shared preliminary versions of the comics: The Nebraska Commission on Indian Affairs shared the drafts with Omaha and Ponca Tribal members, interns, and friends. Informal feedback from these groups assured us that our characters and stories reflected the pivotal influence of Judi gaiashkibos, member of the Nebraska Ponca Tribe, and Henry Payer, member of the Nebraska Winnebago Tribe. Eventually the Tribal C'RONA Comix series was selected by the Native American Program Specialist at Lincoln Public Schools to use in the reading programs for fifty Tribal youth. In this case, the program specialist printed the comics for use by youth, rather than accessing the materials through our website.

We decided to create our Tribal comic around both fictional and historical characters. It features the relationship between a young Native boy, a young doctor, and the doctor's long deceased relative, the first Native American physician, Susan La Flesche (Ferry, 2019). We included a trickster coyote to provide light-hearted elements. The ghost of Susan La Flesche appears throughout the story to give moral support to her hard-working fictional descendent, a Native doctor (figure 8).

The young boy and his coyote sidekick join the doctor and ghost to visit a family where they find the grandfather is deathly ill with COVID-19 (figure 9). The grandfather eventually dies and joins Susan La Flesche as another ghost.

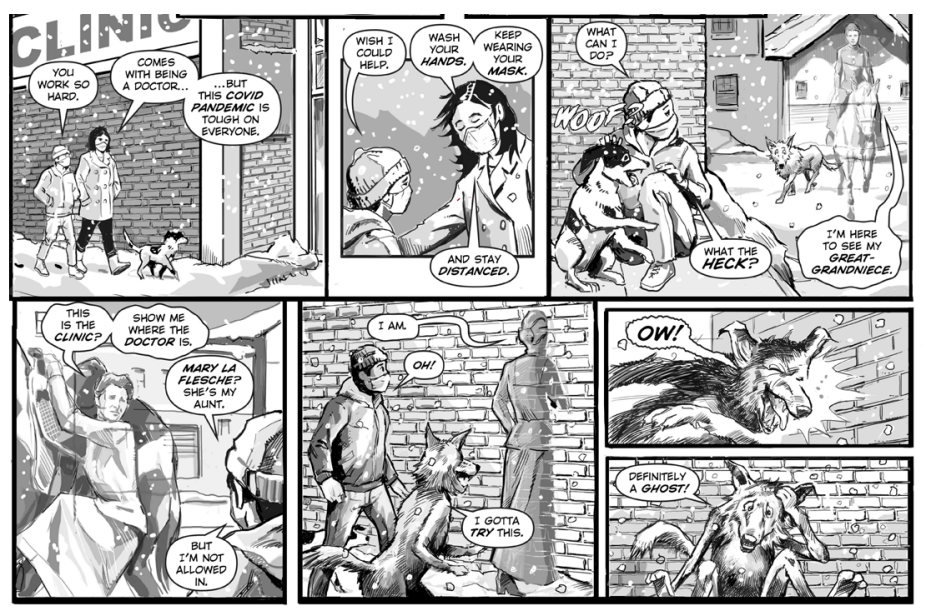

Figure 8. Excerpt from Tribal C'RONA Comix, p. 1.
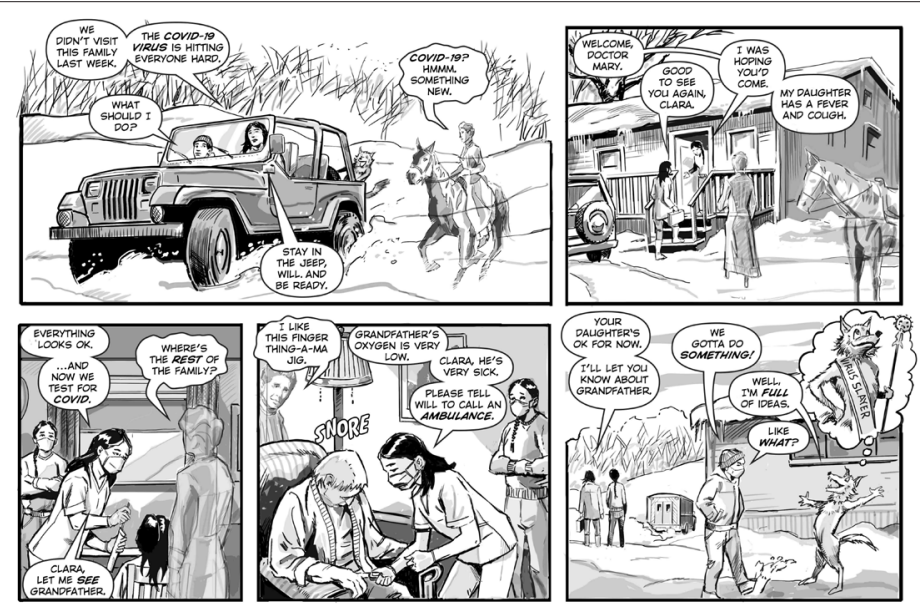

Figure 9. Excerpt from Tribal C'RONA Comix, p. 2.

Throughout the course of the story, the coyote invents one crazy scheme after another to rid the community of the viruses. He convinces the boy to help him creating a make-believe village to lure the viruses away. After that fails, the coyote dresses in a balloon suit where he predicts, "The viruses will cling to this like a mother ship!" The boy eventually sees through the absurdity of the coyote's hair-brained schemes. In the end, a group of Native doctors arrive to help the community defeat the virus.

Spreading the Word. Our production process for the comics was unlike anything we had experienced in prior projects. The NSF RAPID grants expected deliverables to be produced while the pandemic was still in progress. Since it was not clear how long it would last, we hit the ground running. Our existing SEPA web site, worldofviruses.unl.edu, was still active, so we created new pages for the project and posted new comics online nearly every week starting one month after receiving our grant from the NSF. We made the black and white comics easily printable from the website, and we included code for freely embedding the comics in other sites. Our university sent out press releases on the book and we emailed all 380 public libraries in Nebraska informing them of the resource.

In 2021, the University of Nebraska Press published our book, C'RONA Pandemic Comics (Hall et al., 2021; figure 10) that included the comics and the following five essays written for youth: COVID-19 Is Something New; Tribes and the Pandemic; Bats and the Virus; Tracing Connections to Stop a Pandemic; and Viruses and Giant Viruses.

Several organizations were crucial to the dissemination of the project materials. The Lincoln Public Libraries embedded our comics on their teen page, and the librarians and teen advisers gave us useful feedback. We sent the comics to a large public school district (42,000 students) who gave us feedback and access to survey students and provide our comic books to the entire middle school population of 9400 students. The Nebraska Commission on Indian Affairs em- 


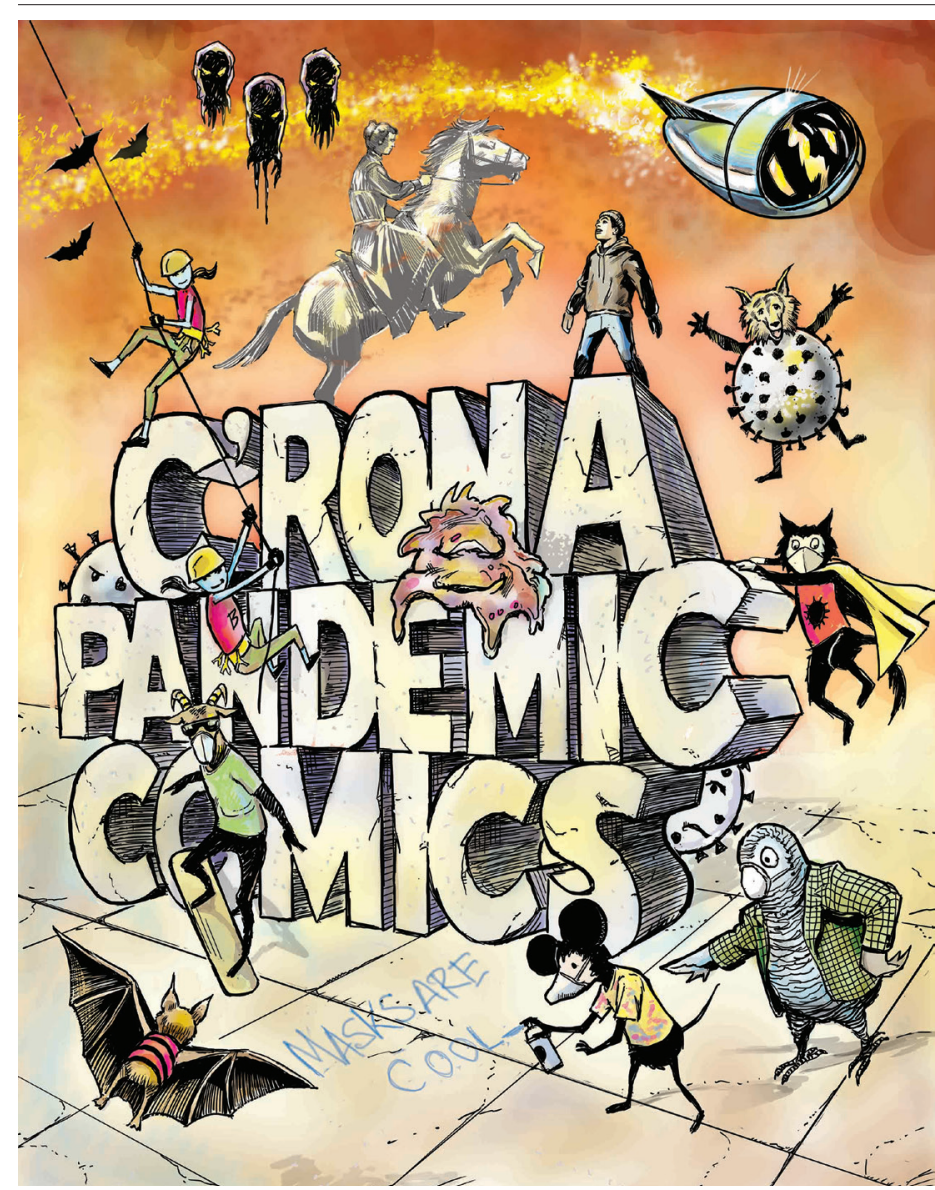

Figure 10. Cover of the book, C'RONA Pandemic Comics, published by the University of Nebraska Press.

braced the project, collaborated on writing the stories, disseminated the comic books to 400 youth in Tribal communities in Nebraska, and publicized the project broadly among Tribal organizations throughout the United States. During 2021, poster-sized versions of the comics are being exhibited at the Nebraska State Capitol, the Nebraska State Office Building for Minority Health Month, the McGoogan Library at the University of Nebraska Medical Center, the Dr. Susan Center, and the Omaha Tribal Clinic.

\section{CONCLUSIONS}

The physicist Frank Oppenheimer, founder of the San Francisco Exploratorium, believed that artists were the most effective communicators of science (Oppenheimer, 1972). Comics allow for the use of sequential art to convey scientific information in narratives that have social and emotional meaning. They are an important, accessible, and inexpensive media form for reaching out to youth with STEM content (Harbaugh, 2008). We know that comics have value for engaging youth with scientific information, particularly among youth with lower science identities (Spiegel et al., 2013). But there is much to learn about how best to use comics as a medium for generating science interest and knowledge, particularly with regard to how they influence the emergence of science identity among youth who are historically underrepresented in science (Barton et al., 2013; Carlone et al., 2014)

During the COVID-19 pandemic of 2020 and 2021, in collaboration with artists and virologists, we developed comic stories that addressed fundamental issues in biology, virology, and network science. Our goal was to help readers understand the complexities of living through a viral pandemic, and we chose to focus on the three themes of 1) the biology of the COVID-19 virus, 2) the relationship of wild animals, particularly bats, to the pandemic, and 3) the impact of the pandemic on Tribal communities.

There are several ways that this project had to overcome challenges posed by creating STEM outreach during a pandemic. We were confronted by the fact that the pandemic was unsettled science, with ongoing uncertainties about the nature of the SARS-CoV-2 viruses and the new disease, COVID-19. At times, we incorporated new information as it was emerging from research laboratories throughout the world. The project drew on a constellation of diverse expertise representing the fields of virology, veterinary medicine, public health, sociology, and network science in our efforts to enhance engagement with the science behind the pandemic. Members of Nebraska Ponca and Winnebago Tribes, Judi gaiashkibos and Henry Payer, helped us create authentic voices that would speak to Native communities.

In the end, this project demonstrated the value of integrating science, art, social science research, and Indigenous perspectives in a framework accessible to the emotional needs of youth. We make no claim, however, that comics will interest everyone or that they should replace other channels for communicating science to young people. Our formative evaluations encouraged us that our comics were effective for many young people, but we also learned that some students do not respond well to this medium, and that it is important to offer a variety of formats when reaching out to a diverse student population. Upon completion of the twenty $C^{\prime} R O N A$ Pandemic Comics, we surveyed a large population of middle school students in more detail to better understand how the comics influenced their understanding and interest in the pandemic, virology, and infectious disease. That study, currently underway, will help us to examine the extent to which youth knowledge about the pandemic is influenced by the comics. This report describes our experience developing comics to help youth understand a pandemic while it was still in progress. What we learned from working with artists and scientists and receiving valuable feedback from youth provides a stepping stone to understanding how to capture the interest of young people in relevant and emerging science. 


\section{AUTHOR INFORMATION \\ Corresponding Author}

Judy Diamond, PhD. Museum Curator of Informal Science Education and Professor of University Libraries, University of Nebraska. Room 225A Love South, Lincoln, NE, 68588-4100.jdiamond1@unl.edu

\section{Author Contributions}

The manuscript was written through contributions of all authors. All authors have given approval to the final version of the manuscript.

\section{ACKNOWLEDGMENTS}

Many of our collaborators at the Nebraska Center for Virology and the University of Nebraska Medical Center had advised our previous comic projects, and they generously gave us continuous feedback as we created educational materials that focused on the current pandemic. We are grateful to St Patrick Reid in the Department of Pathology and Microbiology at the University of Nebraska Medical Center, Peter Angeletti at the Nebraska Center for Virology and the University of Nebraska School of Biological Sciences, David Dunigan at the Department of Plant Pathology at the University of Nebraska, and James Van Etten, Co-Director of the Nebraska Center for Virology, William Allington Distinguished Professor of Plant Pathology at the University of Nebraska, and member of the National Academy of Sciences.

\section{FUNDING SOURCES}

This work is supported by the National Science Foundation through award DRL2028026 (2020-2021). Parts of this publication were also supported by the National Institute of General Medical Sciences at the National Institutes of Health under Science Education Partnership Award R25GM129836. Any opinions, findings, or conclusions expressed in this material are those of the authors and do not necessarily reflect the views of the National Science Foundation or the National Institutes of Health.

\section{ABBREVIATIONS}

NGSS: Next Generation Science Standards; SEPA: Science Education Partnership Award

\section{REFERENCES}

Barton, A. C., Kang, H., Tan, E., O’Neill, T.B., Bautista-Guerra, J., and Brecklin, C. (2013). Crafting a future in science tracing middle school girls' identity work over time and space. American Educational Research Journal, 50(1), 37-75.
Bruna, K., Erikson, S., and Bartholomay, L. (eds.) (2021). Mosquitoes SUCK! Lincoln: University of Nebraska Press.

Carlone, H. B., Scott, C. M., and Lowder, C. (2014). Becoming (less) scientific: A longitudinal study of students' identity work from elementary to middle school science. Journal of Research in Science Teaching, 51(7), 836-869.

Chu, J N., Tsoh, J. Y., Ong, E., and Ponce, N. A. (2021). The hidden colors of coronavirus: The burden of attributable COVID-19 deaths. Journal of General Internal Medicine, 1-3. DOI: $10.1007 / \mathrm{s} 11606-020-06497-4$

Diamond, J., Floyd, T., Powell, M., Fox, A., Downer-Hazell, A., and Wood, C. (2012). World of viruses. Lincoln: University of Nebraska Press.

Diamond, J., Floyd, T., Smith, R., Downer-Hazell, A., Powell, M., Poliwki, N., Fox, A., Spiegel, A., Wonch Hill, T., and McQuilllan, J. (2019). Occupied by microbes. Lincoln: Zea Books.

Diamond, J., Jee, B., Matuk, C., McQuillan, J., Spiegel, A. N., and Uttal, D. (2015). Museum monsters and victorious viruses: Improving public understanding of emerging biomedical research. Curator, 58(3), 299-311.

Diamond, J., McQuillan, J., Hill, P.W., Spiegel, A. N., Smith, R., West, J., and Wood, C. (2016). Viruses, vaccines and the public. Museums and Social Issues, 11(1), 9-16.

Ferry, G. (2019). Susan La Flesche Picotte: A doctor who spanned two cultures. The Lancet, 393(10173), 734.

Gauthier, G. R., Hill, P. W., McQuillan, J., Spiegel, A. N., and Diamond, J. (2017). The potential scientist's dilemma: How the masculine framing of science shapes friendships and science job aspirations. Social Sciences, 6 (1), 14. doi: 10.3390/socsci6010014.

Hall, B., Diamond, J., VanWormer, L., and gaiashkibos, J. (2021). C'RONA pandemic comics. Lincoln: University of Nebraska Press.

Hall, B., West, J., Zimmer, and Diamond, J. (2017). Carnival of contagion. Lincoln: University of Nebraska Press.

Harbaugh, B. (2008). How comics can save us from scientific ignorance. Wired Magazine, 16 (12), 72.

Hill, P. W., McQuillan, J., Spiegel, A. N., and Diamond, J. (2018). Discovery orientation, cognitive schemas, and disparities in science identity in early adolescence. Sociological Perspectives, 61(1), 99-125.

Hill, P. W., McQuillan, J., Talbert, E., Spiegel, A., Gauthier, G. R., and Diamond, J. (2017). Science possible selves and the desire to be a scientist: Mindsets, gender bias, and confidence during early adolescence. Social Sciences, 6(2), 55. doi: 10.3390/socsci6020055.

Hoffman, D. (2009). Reflecting on social emotional learning: A critical perspective on trends in the United States. Review of Educational Research, 79(2), 533-556. 
Hosler, J., and Boomer, K. B. (2011). Are comic books an effective way to engage nonmajors in learning and appreciating science? CBE Life Sciences Education, 10(3), 309-317.

Jagers, R. J., Rivas-Drake, D., and Williams, B. (2019). Transformative social and emotional learning (SEL): Toward SEL in service of educational equity and excellence. Educational Psychologist, 54(3), 162-184.

Jee, B.D., and Anggoro, F.K. (2012). Comic cognition: exploring the potential cognitive impacts of science comics. Journal of Cognitive Education and Psychology, 11(2), 196-208.

Jee, B., Uttal, D., Spiegel, A., and Diamond, J. (2015). Expert-novice differences in mental models of viruses, vaccines, and the causes of infectious disease. Public Understanding of Science, 24(2), 241-256.

Kim, A. Y., Sinatra, G. M., and Seyranian, V. (2018). Developing a STEM identity among young women: A social identity perspective. Review of Educational Research, 88(4), 589625 .

Locke, S. (2005). Fantastically reasonable: Ambivalence in the representation of science and technology in super-hero comics. Public Understanding of Science, 14(1), 25-46.

Matuk, C. F., Diamond, J., and Uttal, D. H. (2009). Heroes, villains and viruses: How graphic narratives teach science. Paper presented at the International Visual Literacy Association (IVLA2009), Chicago, IL.

Matuk, C, Hurwich, T., Spiegel, A. N., and Diamond, J. (2019). How do teachers use comics to promote engagement, equity, and diversity in science classrooms. Research in Science Education, 1-48. https://doi.org/10.1007/s11165018-9814-8

National Research Council (2012). A framework for K-12 science education: Practices, crosscutting concepts, and core ideas. Washington DC: National Academies Press.

NGSS Lead States (2013). Next generation standard: For states, by states. Washington DC, The National Academic Press.

Oppenheimer, F. (1972). The Exploratorium: A playful museum combines perception and art in science education. American Journal of Physics, 40(7), 978-984.

Spiegel, A. N. (2021). Teen feedback on C'RONA Comix: Formative evaluation report. March 2021. University of Nebraska - Lincoln: Methodology and Evaluation Research Core Facility.

Spiegel, A. N., McQuillan, J., Halpin, P., Matuk, C., and Diamond, J. (2013). Engaging teenagers with science through comics. Research in Science Education, 43(6), 2309-2326.

Tai, D. B. G., Shah, A., Doubeni, C. A., Sia, I. G., and Wieland, M. L. (2021). The disproportionate impact of COVID-19 on racial and ethnic minorities in the United States. Clinical Infectious Diseases, 72(4), 703-706.
Tatalovic, M. (2009). Science comics as tools for science education and communication: A brief, exploratory study. Journal of Science Communication, 8(4), 1-17.

Taylor, R. D., Oberle, E., Durlak, J. A., and Weissberg, R. P. (2017). Promoting positive youth development through school-based social and emotional learning interventions: A meta-analysis of follow-up effects. Child Development, 88(4), 1156-1171.

Yellow Horse, A. J., Yang, T-C, and Huyser, K.R. (2021). Structural inequalities established the architecture for COVID-19 pandemic among native Americans in Arizona: a geographically weighted regression perspective. Journal of Racial and Ethnic Health Disparities, 1-11.

Zimmer, C. (2021). A planet of viruses. 3rd edition. Chicago: University of Chicago Press. 